\title{
The management of acute reversible intrinsic renal failure
}

\author{
C. R. BLAGG \\ Department of Medicine, The General Infirmary, Leeds
}

ONCE acute renal failure has developed the clinical course is remarkably similar whatever the aetiology, and can conveniently be divided into two phasesfirstly the phase of renal insufficiency and secondly the recovery phase. The latter commences when renal function has improved sufficiently to correct the biochemical abnormalities.

\section{The phase of renal insufficiency}

The clinical effects of acute renal failure were well described by Salisbury (1958). For 5 days signs and symptoms are usually absent except for increasing anaemia, but by the 6th day the patient is nauseated and slightly confused, with impaired memory or more severe mental changes. By the 7 th day the patient is drowsy with hyperactive reflexes, and by the 8th day progressive twitching and somnolence develop. Convulsions and coma occur on or about the 10th day and death follows shortly afterwards, commonly preceded by a convulsion.

This time scale varies considerably with the rate of protein catabolism (Parsons \& McCracken, 1957), which is influenced in turn by the cause of renal failure (trauma, surgery, etc.) and the presence of complications (haemorrhage and infection, etc.). In general, patients with a blood urea rising less than $30 \mathrm{mg} / 100 \mathrm{ml}$ daily will probably recover adequate renal function before requiring dialysis, whilst those with a blood urea rising faster than $50-60 \mathrm{mg} /$ $100 \mathrm{ml}$ daily (i.e. most of those who have suffered accidental or surgical trauma or are infected), will require frequent dialysis to prevent death from uraemia and its complications.

\section{Fluids}

Patients with anuria depend on extrarenal mechanisms for water excretion and therefore readily develop water intoxication.

The average daily extrarenal loss of water in adults in temperate climates is about $1000 \mathrm{ml}$ due to insensible losses from skin, lungs and in faeces. This is partly replaced by water of oxidation from tissue metabolism $(300 \mathrm{ml})$ and pre-formed tissue water liberated during metabolism $(125 \mathrm{ml})$ leaving some $500 \mathrm{ml}$ to be supplied daily by fluid and dietary intake (Bluemle, Potter \& Elkinton, 1956). Early regimens, such as that of Bull, Joekes \& Lowe
(1949), recommended a fluid intake of $800-1000 \mathrm{ml}$ daily. This was sufficient to prevent weight loss and gradually produced overhydration with development of hyponatraemia (Loughridge et al., 1960). This overhydration explains early reports of increased extracellular fluid volume in uraemic patients (Sirota \& Kroop, 1951; Bluemle et al., 1956).

The present view is that the daily fluid requirement of adults with acute renal failure in temperate climates is some $400 \mathrm{ml}$ plus the volume of any sensible fluid loss (Merrill, 1965). The simplest index of fluid balance is daily weight loss which should average $200-500 \mathrm{~g}$ daily (Swan \& Merrill, 1953). In addition plasma sodium can be monitored and should remain relatively constant. A fall in plasma sodium suggests overhydration, and the treatment of hyponatraemia in these circumstances is further limitation of fluid intake rather than infusion of sodium chloride.

In centres with a policy of early dialysis using an artificial kidney capable of ultrafiltration, a more liberal fluid intake is permissible, provided excessive overhydration is avoided.

\section{Sodium and chloride}

Extrarenal losses of sodium and chloride are small in the anuric patient and there should be little change in plasma sodium and chloride levels. Hyponatraemia and hypochloraemia represent over-hydration due to excessive water intake. Routine sodium replacement is not required unless there are obvious losses, and if sodium salts are given for other purposes (e.g. intravenous sodium bicarbonate for acidosis) care must be taken to avoid circulatory overloading and pulmonary oedema.

\section{Potassium}

Potassium is released from depleted glycogen stores, destruction of tissue protein, intravascular haemolysis, destruction of blood extravasated into tissues and the shift of potassium from within the cells due to progressive metabolic acidosis (Keating et al., 1953). Whatever the mechanism of potassium release potassium intoxication may result. This is related partly to the serum potassium levels and also to associated hyponatraemia, hypocalcaemia, hyper- 
magnesaemia, and acidosis. As a result toxic effects on both cardiac and skeletal muscle may develop.

Electrocardiographic changes do not correlate precisely with serum potassium levels but nevertheless follow a predictable pattern and, as they represent changes occurring in the cardiac conducting system, are the best monitor of potassium intoxication (Merrill et al., 1950). Lengthening of the $P R$ interval, peaking of the $T$ wave, and flattening of the $P$ wave occur early and as these changes become more prominent the $Q R S$ complex widens. Later the $S T$ segment merges with the upstroke of the $T$ wave and ultimately there may develop a sine-wave pattern followed finally by cardiac arrest.

Occasionally muscular weakness, leading to paralyses, including respiratory paralysis, is observed and usually indicates severe potassium intoxication requiring urgent treatment.

Prevention of potassium intoxication includes potassium-free diets, adequate surgical debridement and drainage, minimizing protein catabolism by treatment of infection, and providing an adequate calorie intake. In addition any blood transfused should be not more than a few days old.

If the serum potassium level is more than $7 \mathrm{mEq} / 1$ the most rapid treatment, acting within minutes, is infusion of hypertonic sodium bicarbonate. The sodium ion antagonizes the cardiac effects of potassium and also potassium returns intra-cellularly as a result of treatment of the acidosis (Keating et al., 1953). These effects are short-lived (1-2 hr) and must be reinforced by exchange resins or dialysis. Other slower emergency treatments include infusion of $200 \mathrm{ml}$ of hypertonic $(5 \%)$ sodium chloride or $100 \mathrm{ml}$ of $10 \%$ calcium gluconate (Meroney \& Herndon, 1954) or most commonly infusion of hypertonic glucose together with insulin (100-200 $\mathrm{ml} \mathrm{50 \%} \mathrm{glucose}+20$ units soluble insulin) in order to deposit glycogen with associated potassium and phosphate into the cells (Merrill et al., 1950). This last treatment is rather slow in onset $\left(\frac{1}{2}-1 \mathrm{hr}\right)$ but its effect may last for several hours.

These emergency measures should be reinforced by the use of cation-exchange resins either orally or per rectum. Originally an ammonium cycle resin (Elkinton et al., 1951) or a sodium cycle resin (Evans et al., 1953) were used. More recently a palatable fine-mesh resin in the sodium cycle (Resonium A) has been developed which can be given orally in dosage of up to $100 \mathrm{~g}$ sometimes together with sorbitol (Flinn, Merrill \& Welzant, 1961). The latter is a poorly absorbed osmoticallyactive alcohol which accelerates gastro-intestinal emptying. Sorbitol therefore facilitates water, sodium and potassium loss by diarrhoea, and simultaneously the resin exchanges sodium for potassium, replacing sodium lost by action of the sorbitol.
Alternatively a resin in the calcium phase may be given prophylactically in a daily dose of say $50 \mathrm{~g}$ orally (Berlyne et al., 1966).

The most effective means of removing excess potassium from the body is either by haemodialysis or peritoneal dialysis. This should certainly be used if hyperkalaemia recurs, or is accompanied by other indications for dialysis, or if other methods are impracticable.

\section{Acidosis}

Acidosis in acute renal failure results from retention of hydrogen ions associated with phosphate, sulphate and other acids released by oxidation of amino acids, and oxidation and hydrolysis of phospho-protein residues (Relman, Lennon \& Lemann, 1961; Lemann et al., 1963), and also from gastro-intestinal loss of bicarbonate, usually with sodium. The biochemical result is a decrease of serum bicarbonate but this is essentially a compensatory mechanism due to buffering of the acidosis by respiratory $\mathrm{CO}_{2}$ loss, leading in extreme states to Kussmaul breathing. The low serum bicarbonate in acute renal failure is therefore not usually due to bicarbonate loss, and unless the patient has severe symptoms little is to be gained by giving sodium bicarbonate. In addition, the resulting expansion of extracellular fluid volume may produce cardiac failure and pulmonary oedema and in the presence of a depressed serum ionized calcium rapid infusion of an alkaline solution may precipitate tetany. If acidosis requires treatment gastric suction may help but more commonly such patients require dialysis. This is by far the most physiological method of treating acidosis as it results in the extrarenal removal of metabolites.

\section{Calcium and phosphorus}

Twitching and convulsions occurring in acute renal failure are not usually due to calcium loss and hypocalcaemia. There is some depression of ionized calcium but no large net calcium loss from the body. Occasionally infusions of calcium gluconate help to improve twitching but large quantities of calcium salts should be avoided because they may produce metastatic calcification.

Retention of phosphate should be minimized by decreasing protein catabolism and by avoiding phosphate intake. The main effect of phosphate accumulation is metabolic acidosis and during the short course of acute renal failure changes in serum calcium and phosphate are usually of no clinical importance.

\section{Magnesium}

Hamburger (1957) suggested that hypermagnesaemia might be the cause of many of the neuro- 
logical complications of uraemia, but Locke, Merrill \& Tyler (1961) were unable to confirm this.

\section{Calorie intake}

One of the main aims of the conservative treatment of acute renal failure is to decrease protein catabolism. This is because the products of protein catabolism retained within the body include nitrogenous metabolites, hydrogen ions, and potassium ions.

It is well known that non-protein calories have a protein-sparing action and that if other sources of calories are inadequate protein is utilized to provide calories. Also metabolism of fat and carbohydrate produces no nitrogenous residues but only water and $\mathrm{CO}_{2}$. It has therefore become customary to give these patients as high a carbohydrate intake as possible to decrease protein catabolism and help complete oxidation of ketones resulting from body fat catabolism.

Early studies in normal people suggested the optimal quantity of carbohydrate for protein sparing was $100 \mathrm{~g}$ daily and Butler et al. (1945) and Gamble (1947) believed that nitrogen production was not significantly affected by further increasing carbohydrate intake.

Borst (1948) and Bull et al. (1949) were among the first to emphasize the importance of a protein-free high-calorie diet in acute renal failure, and their original regimens contained both carbohydrate and fat. Fat, however, may cause nausea, diarrhoea, and fat pneumonia, and is little or no more effective in protein-sparing than carbohydrate. Because of toxic effects (Alexander \& Zieve, 1961), intravenous fat emulsions are best avoided in these patients.

As a result, Merrill (1965) has suggested that fat has no part to play in the treatment of uncomplicated renal failure, and that adequate quantities of carbohydrate should be given. For some time the commonest dietary regimen was $100 \mathrm{~g}$ of glucose given together with the daily allowance of $400 \mathrm{ml}$ of water. Most patients will tolerate this mixture orally, although occasionally anti-emetic drug therapy may be required (Parsons, Blagg \& Williams, 1963). Recently, Wolthuis (1961), after further studies on normal subjects, suggested that diet in acute renal failure should always supply more calories than $100 \mathrm{~g}$ of carbohydrate. Studies in patients with renal failure have given contradictory results. Gjørup (1958) showed an apparent relationship between carbohydrate intake and protein-sparing but Bluemle et al. (1956) and Taylor (1957) could not confirm this. More recently Parsons \& Fore (1963) have shown that with sufficient carbohydrate intake increased protein-sparing can occur even in patients with severe catabolic response following injury.

As a result patients with acute renal failure should be given as high a carbohydrate intake as practicable. Because of limitations of fluid intake this must be given as a concentrated glucose solution although $\stackrel{\otimes}{\varnothing}$ most patients are unable to tolerate greater con- $C$ centrations than $25 \%$ glucose by mouth. A recent $\vec{F}$ useful development is the preparation 'Hycal' pro- $\stackrel{\text { ? }}{?}$ duced by Beechams. This is a hydrolysate of starch ${ }^{\circ}$ called 'liquid glucose', and is readily absorbed from the gut (Butterfield, Sargeant \& Whichelow, 1964). Four bottles of this daily will provide 1700 calories $\_$ with only $400 \mathrm{ml}$ of water.

Occasionally patients may be unable to take $\vec{\circ}$ calories by mouth and it is necessary to use the intravenous route but this is best avoided if possible $\vec{\omega}$ because of risks of infection and thrombosis (Bansmer, Keith \& Tesluk, 1958; Blagg, 1961).

Other theoretical sources of non-protein calories are fructose and ethyl alcohol.

\section{Anabolic steroids}

The effect of androgenic hormones on protein metabolism is well known (Kochakian, 1946). Selye (1940) and Masson, Cocoran \& Page (1949) showed that testosterone propionate prolonged sur- $\vec{D}$ vival in nephrectomized animals, provided there was no infection. Testosterone and testosterone propionate have also been used in uraemic patients $\mathscr{\mathscr { C }}$ (Freedman \& Spencer, 1957; Merrill, 1965) but usually. the virilizing action outweighed any anabolic effect.

The synthesis of steroids with a greater anabolicandrogenic ratio re-awakened interest in their use in acute renal failure. We have shown (McCracken \& Parsons, 1958; Blagg \& Parsons, 1960) that nor- $\mathbb{D}$ ethandrolone is very effective in reducing urea $\underset{F}{\vec{F}}$ formation in patients with post-partum renal $\frac{0}{3}$ failure and also in some patients with renal failure from other causes (Gjørup \& Thaysen, 1960; Blagg and Parsons, 1961). Not all patients respond, particularly those with high rates of protein catabol- 3 . ism from trauma or infection, possibly because $\bar{\sigma}$. anabolic agents cannot prevent breakdown of 3 . devitalized tissue or are antagonized by excessive $\delta$ production of corticosteroids (Brochner-Mortensen, Gjørup \& Thaysen, 1959; Llaurado, Trunnell \&음 Claus, 1960).

Wolthuis' work (1961) suggested that the protein- $\frac{D}{2}$. sparing action of carbohydrate and anabolic steroids $\overline{\bar{N}}$ is greater in well nourished subjects, and it is known o that essential amino acids are necessary for nitrogen $N$ equilibrium (Rose, Coon \& Lambert, 1954). As a స్ల result, we have described balance studies showing 0 that if patients with acute renal failure are fed pro--o

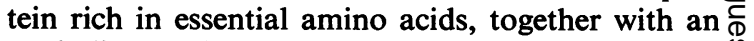
anabolic steroid, no significant increase in the rate $\stackrel{\mathcal{P}}{+}$ of urea production occurs, as compared with the $\square$ standard regimen, despite the increased protein intake, i.e. there is some improvement in protein $\triangle$ balance (Blagg, Parsons \& Young, 1962). Similar $\stackrel{\mathbb{Q}}{\varrho}$ results have also been described by Lawson et al. (1962). 
We would therefore suggest that in a centre where dialysis is available, patients with acute renal failure should be given a liberal food intake, preferably milk, eggs and glucose. Our practice is to give $500 \mathrm{ml}$ of milk, three eggs, and $25 \mathrm{~g}$ of sucrose daily and in addition we give calories in the form of 'Hycal' liquid glucose. Water balance may be more difficult to control under these circumstances but this, together with earlier dialysis as required, has produced improved survival in our patients.

\section{Vitamins}

Patients with acute renal failure should receive an adequate vitamin intake either orally or parenterally. Vitamin requirements may be increased in this condition and water-soluble vitamins will be lost during dialysis.

\section{Complications of acute renal failure Anaemia}

Anaemia in acute renal failure results from several factors including blood loss, haemolysis and bone marrow depression. It does not respond to any known treatment except blood transfusion. However, in the uraemic patient, transfused red blood cells have a shortened survival time (Emerson, 1948) and for this reason, and because of the possible potassium content, transfused blood should be as fresh as possible. It is preferable to use packed cells rather than whole blood as the deficiency is of haemoglobin rather than plasma volume; in addition, old blood contains citrate which may bind calcium producing tetany and convulsions. Usually anaemia in these patients becomes stabilized, presumably because a balance occurs between marrow depression and haemolysis on the one hand and the stimulus to erythropoiesis from decreased oxygen carrying capacity on the other (Nathan et al., 1964). It is our practice not to transfuse patients until the packed cell volume falls below 25 as clinical effects attributable to anaemia do not develop until this stage. Excessive transfusion carries the risk of pulmonary oedema. The anaemia of renal failure does not respond to iron, vitamin $B_{12}$, folic acid or other vitamins unless there is a superimposed deficiency of these compounds.

\section{Infection}

The most common cause of death in patients with acute renal failure is bacterial infection (Balch, 1955; Parsons \& McCracken, 1959; Maher \& Schreiner, 1962). Infection may enter from the site of trauma and it is known that both uraemia and malnutrition interfere with resistance to infection and wound healing. One of the dangers of infection is the resulting protein catabolism. The cause of the increased susceptibility to infection in these patients is un- known, as antibody production and phagocytosis are apparently normal (Balch, 1955).

Patients should have swabs cultured from all body orifices but prophylactic antibiotic treatment should not be administered without definite evidence of infection because of the danger of infection with resistant organisms (Barnes et al., 1959). Leucocytosis occurs commonly even in the absence of infection (Swan \& Merrill, 1953) and fever may be absent (Shupack, Urichek \& Merrill, 1960) making it difficult to diagnose infection.

When antibiotic treatment is given it should be remembered that in these patients antibiotics excreted primarily by glomerular filtration accumulate in the body producing much higher blood levels and the risk of toxic manifestations (Kunin et al., 1959). This is particularly important with streptomycin, kanamycin and colistin (MacKay \& Kaye, 1964), therapeutic blood levels of which may persist for 7-10 days following a single intramuscular injection of $1 \cdot 5-2 \mathrm{~g}$.

Efforts should be made to remove any infected or gangrenous tissue and to drain infected cavities. It is quite possible to perform necessary major surgery on uraemic patients provided control by dialysis is available.

Pneumonia is common because of inadequate respiratory movements and accumulation of secretions. It should be treated in the usual fashion. When necessary there should be no hesitation in performing a tracheotomy.

Urethral catheters should be avoided whenever possible because of the risk of infection. It is unnecessary to know the daily urine volume during the oliguric phase as this will not materially affect fluid requirements, and it soon becomes obvious when significant urine output returns. When, for other reasons, it is necessary to use a catheter some form of closed drainage is essential.

\section{Gastro-intestinal tract}

Anorexia, nausea and vomiting are common in patients with acute renal failure once the blood urea rises above $200 \mathrm{mg} / 100 \mathrm{ml}$. Vomiting results in extrarenal losses of electrolytes and the risk of inhalation pneumonia. Treatment is limitation of oral fluids and use of drugs such as chlorpromazine.

Diarrhoea occasionally occurs and results in a beneficial loss of potassium, and also sodium loss which may require replacement. Occasionally in advanced uraemia with a bleeding tendency, diarrhoea may be associated with melaena.

Parotitis is occasionally seen but good oral hygiene should prevent this.

\section{Central nervous system}

Drowsiness, disorientation, delusions and coma occur in the late stages of uraemia. In patients with 
potentially reversible renal failure these complications should be prevented by early dialysis. When sedation is needed paraldehyde is preferable because barbiturates tend to accumulate in these patients. Chlorpromazine, used to prevent nausea and vomiting, also has some sedative value. Sparine is another useful drug.

Epileptic fits are usually due to over-hydration or to severe hypertension, or follow too rapid dialysis. The patient with potassium intoxication occasionally dies during a convulsion, probably associated with a cardiac arrhythmia.

Immediate treatment of the patient who develops fits is sedation. If due to overhydration, dialysis is required using either an artificial kidney capable of ultrafiltration or a dehydrating peritoneal dialysis. If fits are due to hypertensive encephalopathy this should be treated appropriately. Convulsions associated with dialysis are due to too rapid biochemical changes (see below).

The prevention of convulsions requires avoidance of over-hydration and hypertension, and of too rapid dialysis in patients with advanced uraemia.

\section{Cardio-vascular system}

Pulmonary oedema and congestive heart failure result from inadequate fluid and electrolyte control so prevention depends upon fluid and electrolyte restriction. If they develop treatment is in the usual fashion. Morphia should only be used in small doses as it may precipitate vomiting. Aminophylline may be useful. If the packed cell volume is not too low venesection is sometimes helpful. The most effective way of removing large quantities of fluid and electrolytes is ultrafiltration or dehydrating peritoneal dialysis.

Hypertension only needs treatment if severe. The usual drugs are used, although it should be remembered that they will accumulate in these patients.

Digitalis is occasionally necessary in the treatment of heart failure in patients with acute renal failure but should be used with great care. It is mainly excreted through the kidney and so has a prolonged half-life in the body in renal failure. Intravenous digitalization should be avoided and it should be remembered that sudden changes in potassium levels during treatment may produce toxic effects in the digitalized patient. Digitalis should therefore be used with great care in acute renal failure, particularly if dialysis may be required.

Pericarditis occurs in the late stages of uraemia and so can usually be avoided by early dialysis. If it develops the pain may be treated by analgesics. Occasionally haemorrhagic pericarditis may produce cardiac tamponade.

\section{Clotting defects}

Bleeding is common in advanced uraemia and various causes for this have been found. Haemor $\stackrel{\mathbb{D}}{2}$ rhage may occur from any site and occasionally. requires transfusion of platelet-rich plasma for control (Rath, Maillard \& Schreiner, 1957). In? advanced uraemia dialysis is essential for control of bleeding.

\section{Dialysis in acute renal failure}

Many methods have been used to remove the protein metabolites accumulated in uraemia from $\overrightarrow{0}$ the body by extrarenal means.

Diaphoresis and purgation are not very effective्্. and the associated water and electrolyte losses mayt aggravate the uraemia. Exchange transfusions, sug $\frac{0}{3}$ gested by Thalhimer (1938), are also ineffective because many of the substances accumulating in $\omega$ uraemia are distributed throughout the total bodye water. Blood has been circulated extracorporeally through ion exchange columns (Muirhead \& Read 8 1948) but this only removes electrolytes. Moreo recently charcoal columns have been used by Dunea_ \& Kolff (1965), Kolobow \& Dedrick (1966) and bys Blaney, Lindan \& Sparks (1966), and the suggestion has been made by Chang (1966) that charcoal andappropriate enzymes could be contained in semi- $\odot$ permeable microcapsules. Such methods are still in the experimental stages.

The gastro-intestinal tract has also been used. Oschner (1946) employed gastric lavage, Goudsmito (1941) used irrigation of the small intestine throughơ multiple-lumen tubes and Schloerb (1958) suggested $\mathbb{Q}$ gastrodialysis. These procedures have little clinical $\overrightarrow{5}$ application in the management of acute renal 3 failure because of inadequate clearance and because electrolyte balance may be difficult to maintain.

Thus the practicable methods of extracorporealo dialysis in acute renal failure remain haemodialysis, using an artificial kidney, or peritoneal dialysis.

\section{The artificial kidney}

The first artificial kidney was developed by Abel, Rowntree \& Turner (1913) but technical difficulties sufficient to prevent clinical use persisted until the $>$ introduction of heparin as a non-toxic anticoagulant (Haas, 1925) and of cellophane as a suitable mem-No brane (Thalhimer, 1938).

The first practical machine was produced by Kolff \& Berk (1944). Blood was transported along $\omega$ a cellophane tube wound around a large rotating drum which was partly immersed in a tank of rinsinge fluid similar in electrolyte composition to plasma. Many technical problems arose, particularly co-? agulation in the system, which was prevented by using large doses of heparin. The introduction of $\frac{\mathrm{O}_{\mathbb{D}}}{\mathrm{N}}$ plastic materials for the blood lines by Murphy $\frac{\mathbb{\Phi}}{\mathbb{D}}$ et al. (1952) allowed the dosage of heparin to be $\propto$ reduced. More recently techniques for regionalo heparinization have been developed allowing the use $\delta$ 


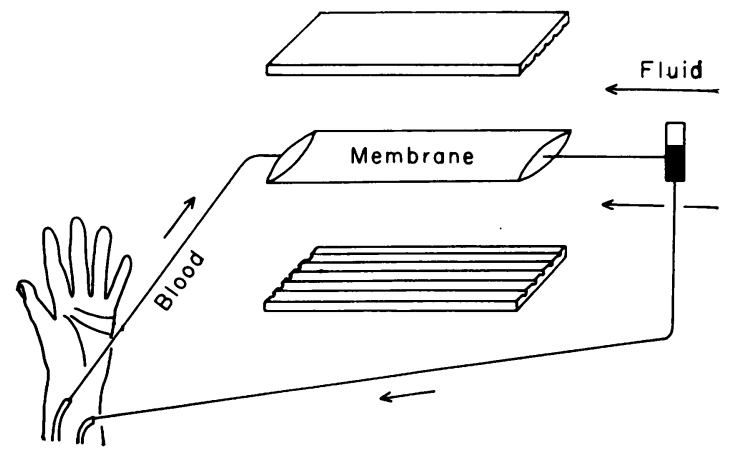

FIG. 1. Diagram of the principles of the Kiil kidney. Blood flows between two cellophane membranes, and dialysing fluid flows counter-current outside the cellophane.

of heparin even in patients who are bleeding at the time of dialysis (Anderson \& Kolff, 1959).

Alwall (1947) and Murray (1947) devised machines in which the cellophane tube was wrapped between stationary drums placed vertically in a tank of irrigating fluid. Skeggs \& Leonards (1948) described a fundamentally different method of dialysis using sheets of cellophane interposed between grooved rubber mats. The blood circulated between the membranes by means of a pump and the irrigating fluid circulated on the outside of the cellophane. Kiil (1960) improved on this design by replacing the rubber mats with polypropylene plates and by altering the blood path entering and leaving the cellophane sheet (Figs. 1 and 2). In these models ultrafiltration is possible since the membrane is supported and blood can be circulated under pressure.

Other machines include that of Inouye \& Engelberg (1953) developed by Kolff \& Watschinger (1956) and now commercially available as the 'Disposable Twin-Coil Kidney'. This has the advantage of a disposable pre-sterilized unit, the cellophane being rigidly supported between fibreglass meshing. Various other newer models are at present being tested.

Thus all present-day artificial kidneys consist of an apparatus by which blood and dialysing fluid are brought together, separated only by a cellophane membrane. The cellophane contains capillary channels of pore radius some $30 \AA$ and through these channels solutes may pass from blood to rinsing fluid or vice versa. The size of the channels is such that substances of molecular weight up to 300 are

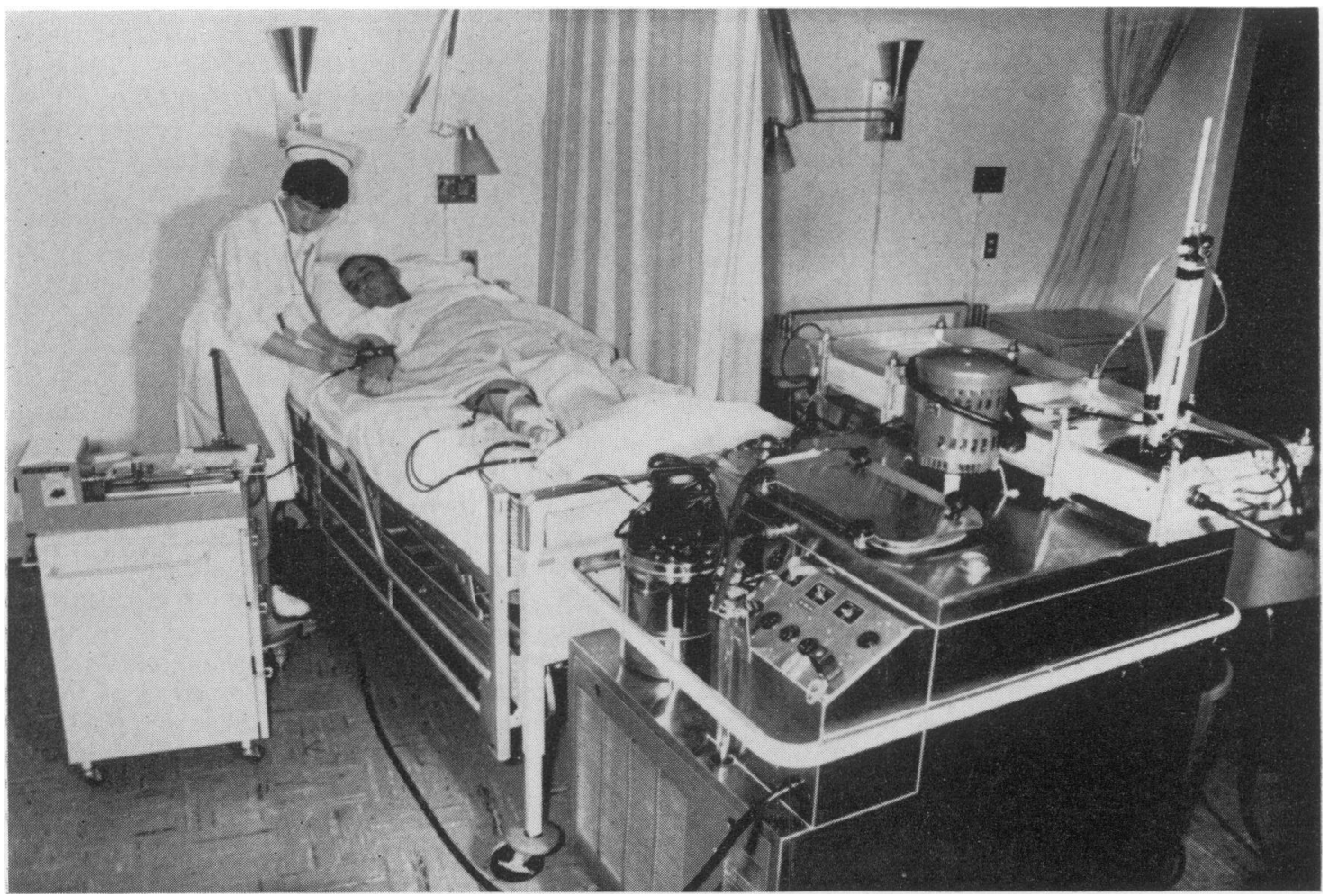

FIG. 2. Dialysis with a Kiil kidney. The dialyser is resting on top of the tank of dialysis fluid. 
able to pass in accordance with any concentration gradient which may exist. The dialysing fluid contains electrolytes in the same proportions as plasma water so that during the course of dialysis correction of any electrolyte and acid-base imbalance occurs. The concentration gradient for urea, creatinine, etc., is from blood to dialysing fluid and this is kept high either by changing the bath fluid every $2 \mathrm{hr}$ or else by a continuous flow of fresh dialysing fluid through the machine.

In addition to correcting biochemical abnormalities it is sometimes necessary to remove water from the body of the patient with acute renal failure who has become overhydrated. Those dialysers in which the cellophane membrane is firmly supported are able to do this by the process of ultrafiltration in which the pressure in the blood line is raised thus producing a pressure gradient across the membrane.

One of the main disadvantages of the rotating coil type of machine is that ultrafiltration is impossible because the cellophane is not rigidly supported. As a result, fluid has to be removed by increasing the osmolality of the tank fluid using glucose, any hyperglycaemia occurring being controlled by the use of insulin (Lewis et al., 1952).

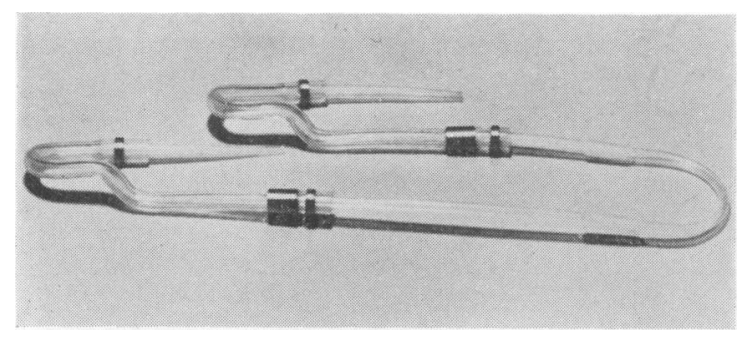

FIG. 3. Shunt.

\section{Connection of the patient to the artificial kidney}

One of the problems in using the artificial kidney is connection of the apparatus to the patient. In the early days cannulae were inserted into an artery and vein in the forearm by surgical cut-down and removed after each dialysis. A great technical advance was the development of an indwelling shunt by Scribner's group (Scribner et al., 1960a; Quinton, Dillard \& Scribner, 1962) (Fig. 3). This consists of teflon tips placed in the radial artery and a forearm vein and connected to a removable teflon shunt by silastic tubing which emerges from under the skin. The shunt may be replaced by connections to the artificial kidney whenever dialysis is required and between dialyses the patient has a small-bore arteriovenous shunt, too small to produce cardio-vascular effects. Clotting does not occur because of the use of teflon and silastic tubing.

\section{Complications of haemodialysis}

These include cardiac arrhythmias resulting from $\stackrel{\complement}{\hookrightarrow}$ rapid correction of the biochemical abnormalities, $\underset{\vec{s}}{\vec{P}}$ bleeding resulting from heparinization and occa- $-\overrightarrow{0}$ sionally vomiting. Infection may occur at cannula등 sites.

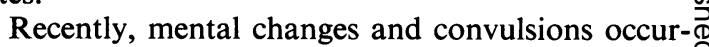
ring during the course of dialysis have attracted attention, and it has been found that the EEG ${ }^{\infty}$ changes of uraemia may become aggravated or may $\vec{O}$ first appear during dialysis. This is associated with $\overrightarrow{\vec{\omega}}$ slow clearance of urea from the cerebro-spinal fluid and brain cells resulting in an osmotic gradiento causing water shift into CSF and brain with cerebral 3 . oedema. Consequently, headaches, delirium and. convulsions may result (Kennedy et al., $1963 ; \omega$ Peterson \& Swanson, 1964) and increases in intra- ${ }_{\infty}$ cranial and intraocular pressure have been recordedin

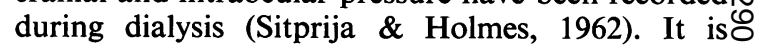
therefore advisable to perform dialysis before gross응 biochemical changes develop so that large shifts of $\rightarrow$ fluids and electrolytes do not occur.

Technical failure of the dialysis due to leaksㅡㅡㄹ. occurring in the cellophane membrane or to clotting $\vec{\bullet}$ in the blood circuit are unusual and of no consequence provided that the amount of blood lost is negligible.

\section{Peritoneal dialysis}

The first experiments with peritoneal lavage were performed by Wegner (1877) and the technique was first used clinically by Ganter (1923). Further refinements have since been made, particularly by $\overrightarrow{\overrightarrow{0}}$ Fine, Frank \& Seligman (1946) and by Boen (1959, 1961, 1964). The principle of peritoneal dialysis is the removal of solute and water by transfer across the peritoneum which acts as a semi-permeable $\frac{0}{3}$ membrane. Because of the simplicity of the technique and the development of commercially avail- $\frac{5}{3}$ able packs peritoneal dialysis has become extremely. popular in the last 4 or 5 years both as a means of $\bigcirc$ treatment for acute renal failure and in the management of patients with chronic renal failure.

A plastic tube is introduced into the peritoneal $\rightarrow$ cavity either through the trocar of a paracentesis set or, in the case of the latest catheter - the 'Trocath'- N over a stylet, the stylet then being withdrawn $N$ (Fig. 4). The catheter is connected to a container of $\mathrm{N}$ dialysing solution, 2 litres of which are then run into ${ }^{\mathrm{\omega}}$ the peritoneum. This is allowed to remain in the peritoneal cavity for a variable period of time in order to equilibrate and is then run out under gravity or with a small negative pressure pump..$_{+}^{+}$ Dialysis occurs across the peritoneal membrane in the same fashion as across the cellophane membrane $\stackrel{\mathbb{D}}{\mathbb{D}}$ of the artificial kidney.

Commercially in Great Britain two types of peri- $\frac{\mathbb{}}{9}$ toneal dialysis fluid are available. Both contain electrolytes in proportions resembling extracellular 8 
fluid and they differ only in their glucose content. The more frequently used solution contains $1.36 \%$ of glucose whilst the other hypertonic solution, which is used for dehydrating patients, contains $6.36 \%$ glucose. By appropriate use of these solutions salt and water may be removed from the patient in addition to nitrogenous metabolites and so hypertension, over-hydration and cardiac failure can be controlled.

Equipment for peritoneal dialysis is simpler than that required for the artificial kidney and more

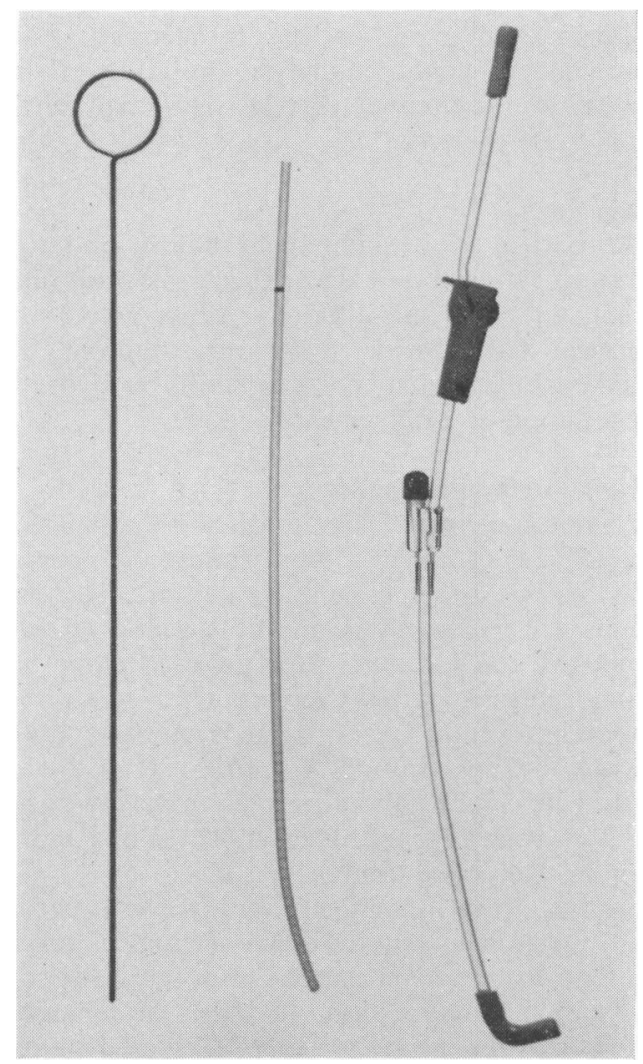

Fig. 4. 'Trocath' peritoneal catheter, stylet and connection.

readily available, but the efficiency of peritoneal dialysis is only some $20-40 \%$ that of the artificial kidney. This disadvantage can be overcome by increasing the total duration of peritoneal dialysis.

Another disadvantage of peritoneal dialysis is protein loss in the outflow fluid which may average $30-40 \mathrm{~g} / 24 \mathrm{hr}$. This can be prevented by reinfusing the first 2-litre outflow intravenously as most of the loss occurs at this time, or else by infusion of protein supplements. The danger of infection during peritoneal dialysis is minimized by using a closed circuit system and with the 'Trocath' there is little danger of intestinal perforation while introducing the catheter. Sodium and water can be removed very effectively and so peritoneal dialysis is often used for the treatment of overhydration. There is no necessity for priming with blood as with the artificial kidney and no necessity for the patient to be heparinized. Peritonitis or recent surgical operations are perhaps a partial contraindication to peritoneal dialysis, but nevertheless a number of workers have seen no harm result from its use in these circumstances (Burns et al., 1962). Peritoneal dialysis is also useful in the treatment of acute poisoning with methyl alcohol or salicylates, particularly in children.

\section{Indications for dialysis in acute renal failure}

The artificial kidney is used to maintain life and well-being during periods of acute renal insufficiency, as originally suggested by Abel, Rowntree \& Turner (1914). Acute renal failure is frequently associated with severe infections and injury. Dialysis merely controls the chemical phenomena and has only indirect effects on these complications.

As recently as 1948 a Lancet editorial suggested that until artificial kidneys became safer they had no place in the treatment of acute renal failure. This view is no longer tenable. Dialysis, by improving biochemical abnormalities in the patient, improves the clinical state and so increases resistance to infection and other complications. It would therefore seem that the most appropriate use of the artificial kidney or peritoneal dialysis is the prevention of development of clinical symptoms due to uraemia. The clinical effects of uraemia are not well correlated with any of the biochemical abnormalities and our present view is that a blood urea concentration greater than $200 \mathrm{mg} / 100 \mathrm{ml}$ is an indication for dialysis in the majority of patients with acute renal failure. Previous indications such as those of Kolff (1954) have now been discarded as a result of work such as that of Scribner \& Caner (1960), Scribner, Magid \& Burnell (1960b) and Teschan, O'Brien \& Baxter (1959). By the use of early dialysis Parsons et al. (1961) were able to demonstrate a considerable fall in mortality in complicated surgical patients with renal failure (Table 1) and this has been general experience throughout the world.

It is obvious that the indications for dialysis are based largely on clinical experience and that dialysis should be used to keep patients in a state of wellbeing rather than for treatment after clinical deterioration has occurred.

The same indications for dialysis apply whether haemodialysis or peritoneal dialysis is to be carried out. Because of recent improvements and simplifications in the technique of peritoneal dialysis it has now become customary to use this for most patients 
with acute renal failure. Peritoneal dialysis is sometimes not sufficiently efficient to control uraemia in those patients who are hypercatabolic from excessive injury and infection but in most other circumstances peritoneal dialysis is perfectly satisfactory. It has the advantage that it requires less medical supervision than haemodialysis.

\section{TABLE 1}

Treatment of patients with traumatic renal failure

\begin{tabular}{cccc}
\hline Indication for dialysis & Year & $\begin{array}{c}\text { No. of } \\
\text { patients }\end{array}$ & $\begin{array}{c}\text { Recovered } \\
(\%)\end{array}$ \\
\hline Clinical deterioration or & & & \\
blood urea $400 \mathrm{mg} / 100 \mathrm{ml}$ & $1956-59$ & 19 & 11 \\
Blood urea $>200 \mathrm{mg} / 100 \mathrm{ml}$ & $1959-60$ & 33 & 60 \\
Blood urea $>200 \mathrm{mg} / 100 \mathrm{ml}$ & $1961-62$ & 49 & 51 \\
Blood urea $>200 \mathrm{mg} / 100 \mathrm{ml}$ & $1963-64$ & 36 & 50 \\
\hline
\end{tabular}

Whichever method of dialysis is used the results of treatment are more dependent upon experience than on the technique available. From the point of view of cost there is little to choose between the two methods of treatment.

In a large general hospital it would seem suitable to treat patients with acute renal failure by peritoneal dialysis provided that adequate staff are available. However, the more seriously ill patients with multiple injuries or severe infection and other complications of uraemia are still best handled in a renal unit where haemodialysis is available and where all the associated facilities of an intensive care unit are to be found. There seems little place for the occasional user of the artificial kidney.

\section{Dialysis in special circumstances Hyperkalaemia}

Dialysis is the most effective way of removing large quantities of potassium from the body. When other forms of treatment for hyperkalaemia fail or are inapplicable, dialysis should be used.

\section{During the recovery phase of renal failure}

There is some confusion of thought as to whether or not dialysis may be required during the recovery phase from acute renal failure (Jackson, 1959). This is because too much attention has been paid in the past to the volume of urine formed rather than to the function which it represents. Correction of biochemical abnormalities at this stage depend upon the balance between endogenous production and available excretory capacity. When renal function is returning the concentration of urea in urine is approximately twice that of plasma (Bull et al., 1949). Using this value and the average daily rise of blood urea during the period of severe oliguria, the 24-hr volume of urine required to halt progression $\stackrel{\bar{\Phi}}{2}$ of uraemia can be calculated, and in patients with $\stackrel{\complement}{\complement}$ marked protein catabolism may be as much as $\overrightarrow{\overline{\vec{s}}}$ $3-3 \frac{1}{2}$ litres of urine daily. It will therefore be appreci- -0 ated that dialysis may still be required in the patient $\frac{\mathrm{C}}{0}$ who has already achieved a quite considerable urine $\overline{\overline{\bar{n}}}$ output if the rate of protein catabolism is high.

\section{Advanced uraemia}

In the patient with advanced uraemia it is prob- $\vec{\circ}$ ably preferable to commence with peritoneal $\vec{\oplus}$ dialysis. This is because rapid changes in urea con- $\omega$ centration may produce mental changes and con-o vulsions as described earlier. If haemodialysis is 3 . used in such patients the dialysis should be of short: duration and a dialyser of relatively small surface $\omega$ area is to be preferred.

\section{Overhydration}

The patient with acute renal failure and over-은 hydration should be treated either by ultrafiltration using a suitable artificial kidney or by a dehydrating $\rightarrow$ peritoneal dialysis using hypertonic solutions. This should enable adequate correction of over-hydration $\vec{\emptyset}$ over a period of $24 \mathrm{hr}$ or so.

\section{Dialysis in chronic renal failure}

It is not appropriate here to discuss the long-term management of chronic renal failure by repeated haemodialysis or peritoneal dialysis. However, patients are frequently seen who develop an acute episode of renal failure superimposed upon pre- $\overrightarrow{\overrightarrow{0}}$ existing chronic renal disease. This sudden de- 3 compensation may result from traumatic injury, infection or dehydration. Careful use of dialysis under such circumstances may improve the patient until such time as renal function proves adequate to maintain them once more.

Another group of patients is those with chronic renal disease who require either urological surgery (e.g. for prostatic obstruction) or surgery for some other unrelated condition. In these circumstances dialysis may be necessary to prepare the patients prior to surgery and to maintain them during the immediate post-operative period, and either haemo- $N$ dialysis or peritoneal dialysis should be used as required.

\section{Other special indications for dialysis}

Dialysis has been used in the treatment of gout (Duncan et al., 1962, 1963; Goldberg et al., 1962). In some patients with gout having such a degree of ? renal failure that they do not respond to uricosuric agents it has been shown that removal of uric acid by haemodialysis will diminish the size of tophi, improve the symptoms and occasionally increase responsiveness to the uricosuric drugs.

The removal of poisons by dialysis is not 8 
considered in detail here. Severe cases of salicylate poisoning are readily treated by peritoneal or haemodialysis: this enables not only removal of salicylates from the body but also the rapid improvement of acid-base and electrolyte disturbances. This form of treatment should be considered in severe cases of salicylate poisoning especially in infants.

In the case of barbiturates opinion is rather more confused. It is our experience that unless the patient has taken phenobarbitone dialysis is not a great deal of value as most other barbiturates are protein bound and do not dialyse very effectively. It is likely that other intensive care measures and enhancing the excretion of the drug through the kidneys are as likely to produce survival as is dialysis.

Dialysis has also been used to treat the acidosis following paraldehyde ingestion (Beier, Pitts \& Gonick, 1963) and to remove ethyl and methyl alcohol from patients.

Those interested in dialysis of poisons and drugs should consult the survey by Maher \& Schreiner (1965).

\section{Treatment during the recovery phase}

The urine volume necessary to correct the biochemical abnormalities of uraemia depends on the rate of protein catabolism. For example, in uncomplicated post-partum renal failure a urine output as little as $750 \mathrm{ml}$ daily may be sufficient for this purpose, but in patients with traumatic uraemia with an extremely high rate of protein catabolism a daily urine volume of as much as 4 litres may be required. In such cases dialysis may still be required if symptoms of uraemia develop despite increasing urine output.

The recovery phase usually commences within 3 weeks of the initial injury, sometimes earlier and occasionally later. If there are no signs of increasing urine output after 3 weeks it is likely that the patient has a poor prognosis. In these circumstances it is justifiable to perform a renal biopsy so that the patient can either be considered for repeated chronic dialysis or treatment may be terminated.

During the recovery phase urinary losses of water and electrolytes may occur. These were emphasized in the past, probably because patients tended to be over-hydrated during the oliguric phase, and as a result considerable diuresis and electrolyte loss occurred at this time (Loughridge et al., 1960). Because of this, patients require careful management and replacement therapy during the recovery phase as well as during the phase of oliguria. It may be inadvisable to replace a large urine volume completely as this may represent elimination of accumulated oedema fluid, and replacement simply serves to maintain the oedematous state. It is necessary to continue daily electrolyte estimations during this period because some patients lose large quantities of potassium, becoming hypokalaemic, and occasionally there may be marked sodium loss.

Tubular function returns relatively rapidly when recovery begins (Swan \& Merrill, 1953) and once the blood urea level starts to fall clinical recovery is usually rapid. During this stage it is important that the patient has an adequate diet including sufficient protein intake, and it may be advisable to continue anabolic steroids. It has been our practice to give these patients at least 1 litre of milk daily together with a high protein diet during this period.

During the recovery phase the urine should be cultured to exclude urinary tract infection developed during the period of oliguria. Patients may also be anaemic at this time and may still need blood transfusion. Usually, iron and vitamin therapy do not help and correction of the anaemia occurs spontaneously as renal function improves.

Full recovery of normal health takes some 3-6 months.

\section{Prognosis in acute renal failure}

Prognosis of uncomplicated acute renal failure due to tubular necrosis is excellent. The majority of patients with renal failure following incompatible blood transfusion or post-partum haemorrhage will recover adequate renal function although slight impairment may persist for some time. For example, persistent impairment of PAH and inulin clearance have been described (Lowe, 1952; Finkenstaedt \& Merrill, 1956) and histological changes in the glomerulus have also been described by Price \& Palmer (1960). The long-term prognosis in these patients is still uncertain.

TABLE 2

Results of dialysis in Leeds (1956-66)

\begin{tabular}{lrc}
\hline & Cases & $\begin{array}{c}\text { Recovered } \\
(\%)\end{array}$ \\
\hline Accidental and surgical trauma & 169 & 48 \\
Pregnancy & 67 & 91 \\
Medical & 80 & 58 \\
Acute and ?'acute' glomerular disease & 71 & 21 \\
Chronic disease for diagnosis & 79 & 0 \\
Urinary tract lesions & 58 & 45 \\
& & \\
\hline
\end{tabular}

The prognosis in other cases of acute renal failure is frequently dependent on associated illness or injury which may determine whether the patient survives or not. Prophylactic dialysis often helps to prevent these complications becoming fatal, but Table 1 shows that even so the mortality of patients with renal failure following trauma remains high. This is because with improved resuscitation the more severely injured patient with multiple injuries survives 
to develop acute renal failure and then dies as a result of his original injury rather than renal failure.

Table 2 summarizes the recovery rate in patients with renal failure treated in Leeds during the last 10 years.

\section{References}

Abel, J.J., Rowntree, L.G. \& TuRner, B.B. (1913) The removal of diffusible substances from the circulating blood by means of dialysis. Trans. Ass. Amer. Phycns, 28, 51.

Abel, J.J., Rowntree, L.G. \& Turner, B.B. (1914) On the removal of diffusible substances from the circulating blood of living animals by dialysis. J. Pharm. exp. Ther. 5, 275.

Alexander, C.S. \& Zieve, L. (1961) Toxic effects and alterations in fasting serum lipids following prolonged use. Arch. intern. Med. 107, 514.

Alwall, N. (1947) On the artificial kidney. Acta med. scand. $128,317$.

ANDERSON, A. \& KolfF, W.J. (1959) Artificial kidney in the treatment of uremia associated with acute glomerulonephritis. Ann. intern. Med. 51, 476.

BALCH, H.H. (1955) The effects of severe battle injury and of post traumatic renal failure on resistance to infection. Ann. Surg. 142, 145.

Bansmer, G., Keith, D. \& Tesluk, H. (1958) Complications following use of indwelling catheter of the interior vena cava. J. Amer. med. Ass. 167, 1606.

Barnes, J., PACE, W.J., Trump, T.S. \& Ellison, E.H. (1959) Prophylactic post-operative antibiotics. Arch. Surg. 79, 190.

BeIER, L.S., PITTS, W.H. \& Gonick, H.C. (1963) Metabolic acidosis occurring during paraldehyde intoxication. Ann. intern. Med. 58, 155.

Berlyne, G.M., Janabi, K., Shaw, A.B. \& Hocken, A.G. (1966) Treatment of hyperkalaemia with a calcium resin. Lancet, i, 169.

BlAGG, C.R. (1961) Treatment of acute renal failure. Med. Press, 246, 199.

BlagG, C.R. \& Parsons, F.M. (1960) The use of norethandrolone in acute renal failure from obstetric causes. Lancet, ii, 577.

BlagG, C.R. \& Parsons, F.M. (1961) Earlier dialysis and anabolic steroids in acute renal failure. Amer. Heart $J$. 61, 287.

Blagg, C.R., Parsons, F.M. \& Young, G.A. (1962) The effect of dietary glucose and protein in acute renal failure. Lancet, i, 608.

Blaney, T.L., Lindan, O. \& Sparks, R.E. (1966) Adsorption; A step toward a wearable artificial kidney. Trans. Amer. Soc. artif. intern. Org. 12, 7.

Bluemle, L.W., JR, Potter, H.P. \& Elkinton, J.R. (1956) Changes in body composition in acute renal failure. $J$. clin. Invest. 35, 1094.

BOEN, S.T. (1959) Peritoneal Dialysis. Assen, Netherlands.

BOEN, S.T. (1961) The kinetics of peritoneal dialysis; a comparison with the artificial kidney. Medicine (Baltimore), 40, 248.

BoEN, S.T. (1964) Peritoneal Dialysis. Thomas, Springfield, Illinois.

BoRsT, J.G.G. (1948) Protein katabolism in uraemia; effects of protein-free diet, infection and blood transfusion. Lancet, i, 824.

Brochner-Mortensen, K., Guorup, S. \& Thaysen, J.H. (1959) The metabolic effect of new anabolic 19-nor-steroids. Acta med. scand. 165, 197.

Bull, G.M., Joekes, A.M. \& Lowe, K.G. (1949) Conservative treatment of anuric uraemia. Lancet, ii, 229.
Burns, R.O., Henderson, L.W., Hager, E.B. \& Merrill, J.P. (1962) Peritoneal dialysis. New Engl. J. Med. 267, $\subseteq$ 1080.

Butler, A.M., Talbot, N.B., Maclachlen, E.A., AppleTON, J.E. \& LinTON, M.A. (1945) Effect of testosteroneo propionate on losses incident to inadequate dietary intakes. J. clin. Endocr. 5, 327.

ButTerfield, W.J.H., SARgeant, S.M. \& Whichelow, M.J. $\frac{\overline{\bar{\omega}}}{\widehat{\sigma}}$ (1964) The metabolism of human forearm tissues after $\mathbb{\Phi}$ ingestion of glucose, fructose, sucrose or liquid glucose.
Lancet, $\mathbf{i}, 574$.

Chang, T.M.S. (1966) Semipermeable aqueous micro- $\overrightarrow{0}$ capsules. Trans. Amer. Soc. artif. intern. Org. 12, 13.

Duncan, H., ElliotT, W., Horn, D.B., KerR, D.N.S., $\overrightarrow{\vec{\omega}}$ Pearson, D.T. \& Robson, A.M. (1962) Haemodialysis in the treatment of gout. Lancet, $\mathbf{i}, 1209$.

Duncan, H., Elliotr, W., Horn, D.B., Kerr, D.N.S., Pearson, D.T. \& Robson, A.M. (1963) Effect of haemodialysis on joint symptoms, urate pool, and renal function $\vec{\omega}$ in familial gout. Metabolism, 12, 252.

DuNEA, G. \& KolfF, W.J. (1965) Clinical experience with the Yatzidis charcoal artificial kidney. Trans. Amer. Soc. artif. intern. Org. 11, 178.

EDITORIAL (1948) Treatment of uraemia. Lancet, i, 221.

Elkinton, J.R., Clark, J.K., SQuires, R.D., Bluemle, 을 L.W., JR \& CROSLEY, A.P. (1950) Treatment of potassium retention in uremia with cation exchange resin. Amer. J. med. Sci. 220, 547.

EMERSON, C.P. (1948) Pathogenesis of anaemia in acute glomerulonephritis. Blood, 3, 363.

Evans, B.M., Milne, M.D., Jones, N.C.H. \& Yellowlees, H. (1953) Ion exchange resins in the treatment of uraemia.. Lancet, ii, 791.

Fine, J., Frank, H.A. \& Seligman, A.M. (1946) The treatment of acute renal failure by peritoneal irrigation. Ann. Surg. 124, 857.

FinkenstaedT, J.T. \& MERRILl, J.P. (1956) Renal function after recovery from acute renal failure. New Engl. J. Med. 254, 1023.

FlinN, R.B., MERrill, J.P. \& Welzant, W.R. (1961) $\overrightarrow{\overrightarrow{0}}$ Treatment of the oliguric patient with a new sodium- 3 exchange resin and sorbitol. New Engl. J. Med. 264, 111.

Freedman, P. \& Spencer, A.G. (1957) Testosterone propionate in the treatment of renal failure. Clin. Sci. 16, 11.

GAMBLE, J.L. (1947) Physiological information gained from studies on the life raft ration. Harvey Lect. 42, 247.

GANTER, G. (1923) Ueber die Beseitigung giftiger stoffe ausi dem Blute durch Dialyse. München. med. Wschr. 70, 1478. 윽

GJORUP, S. (1958) Protein-sparing action of glucose administered intracavally in patients with acute renal failure.음

Acta med. scand. 161, 233.
GJORUP, S. \& THAYSEN, J.H. (1960) The effect of anabolic steroid (Durabolin) in the conservative management of acute renal failure. Acta med. scand. 167, 227.

Goldberg, M., Castleman, L., Friedman, I.S. \& Wallace, o S.L. (1962) The artificial kidney in the treatment of chronic tophaceous gout. J. Amer. med. Ass. 182, 870. N

GoudsMIT, A. (1941) Forced intestinal drainage as a method ${ }^{\mathrm{CW}}$ of extrarenal elimination of urea. Amer.J. Physiol. 133, 297.

HAAS, G. (1925) Versuche der blutaus wasehung am Leben den mit hilfe der Dialyse. Klin. Wschr. 4, 13.

HAMBURGER, J. (1957) Electrolyte disturbances in acutes uraemia. Clin. Chem. 3, 332.

INOUYE, W. \& ENGELBERG, J.A. (1953) A simplified artificial dialyser and ultrafilter. Surg. Forum, 4, 438.

JACKSON, R.C. (1959) Artificial kidneys. Brit. med. J. i, 1041.

Keating, R.E., Wischselbaum, T.E., Alanis, M., Margraf, H.W. \& ElmaN, R. (1953) The movement of potassium during experimental acidosis and alkalosis in the nephrectomised dog. Surg. Gynec. Obstet. 96, 323. 
Kennedy, A.C., Linton A.L., Luke, R.G. \& Renfrew, S. (1963) Electroencephalographic changes during haemodialysis. Lancet, $\mathrm{i}, 408$.

KiIL, F. (1960) Development of a parallel-flow artificial kidney in plastics. Acta chir. scand. 253 (suppl.), 142.

KochaKian, C.D. (1946) The protein anabolic effects of steroid hormones. Vit. and Horm. 4, 255.

KolfF, W.J. (1954) Dialysis in the treatment of uremia. Arch. intern. Med. 94, 142.

KolfF, W.J. \& BeRK, H. (1944) Artificial kidney dialyser with great area. Acta med. scand. 117, 121.

KolfF, W.J. \& WATSChINGER, B. (1956) Further development of a coil kidney, disposable artificial kidney. $J$. Lab. clin. Med. 47, 969.

Kolobow, T. \& DeDRICK, R.L. (1966) Dialysate capacity augmentation at ultra-low flow rates with activated carbon slurry. Trans. Amer. Soc. artif. intern. Org. 12, 1.

Kunin, C.M., Rees, S.B., Merrill, J.P. \& Finland, M. (1959) Persistence of antibiotics in blood of patients with acute renal failure. I, II, III. J. clin. Invest. 38, 1487.

Lawson, L.J., Blaney, J.D., Dawson-Edward, P. \& TONGE, S.M. (1962) Dietary management of acute oliguric renal failure. Brit. med. J. ii, 293.

Lemann, H., JR, Goodman, D.A., Lemmon, E.J. \& Relman, A.S. (1963) Production, excretion and balances of fixed acid in patients with renal acidosis. J. clin. Invest. 42, 951 .

Lewis F.J., Reiser, M.P., Egdahl, R.H., Rafucce, F.L. $\&$ Flink, E.B. (1952) Clinical uses of the artificial kidney. Lancet, ii, 1.

llaurado, J.G., Trunnell, J.B. \& Claus, J.L. (1960) Some effects of simultaneous administration of norethandrolone and cortisone in the rat Acta endocr. 32, 536.

LOCKe, S., MERRILl, J.P. \& TYLER, H.R. (1961) Neurological complications of acute uremia. Arch. intern. Med. 108, 519.

Loughridge, L.W., Milne, M.D., Shackman, R. \& WootTon, I.D.P. (1960) Clinical causes of uncomplicated acute tubular necrosis. Lancet, i, 351 .

LowE, K.G. (1952) The late prognosis in acute tubular necrosis; interim follow up report on 14 patients. Lancet, i, 1086.

MAHer, J.F. \& Schreiner, G.E. (1962) Causes of death in acute renal failure. Arch. intern. Med. 110, 493.

MAHER, J.F. \& Schreiner, G.E. (1965) The clinical dialysis of poisons. Trans. Amer. Soc. artif. intern. Org. 9, 349.

Masson, G.M.C., Corcoran A.C. \& Page, I.H. (1949) Dietary and hormonal effects in experimental uremia. J. Lab. clin. Med. 34, 925.

MACKAY, D.N. \& KAYE, D. (1964) Serum concentration of colistin in patients with normal and impaired renal function. New Engl. J. Med. 270, 394.

McCracken, B.H. \& Parsons, F.M. (1958) Use of nilevar (17-ethyl-19-nortestosterone) to suppress protein catabolism in acute renal failure. Lancet, ii, 885 .

Meroney, W.H. \& Herndon, R.F. (1954) The management of acute renal insufficiency. J. Amer. med. Ass. 155, 877.

MERRILL, J.P. (1965) The Treatment of Renal Failure. Heinemann, London.

MerRill, J.P., LeVine, H.D., Somerville, W. \& SMith, S., III (1950) Clinical recognition and treatment of acute potassium intoxication. Ann. intern. Med. 33, 797.

MUIRHEAD, E.E. \& ReID, A.F.A. (1948) A resin artificial kidney. J. Lab. clin. Med. 33, 841.

MurPhy, W.P., JR, SWaN, R.C., Walter, C.W., Weller, J.M. \& MERRILL, J.P. (1952) Use of artificial kidney. J. Lab. clin. Med. 40, 437.

MurRay, G. (1947) Development of artificial kidney. Arch. Surg. 55, 505.

Nathan, D.G., Shupak, E., Stohlman, F.S., Jr \& Merrill, J.P. (1964) Erythropoiesis in anephric man. J. clin. Invest. 43, 2158.

Oschner, A. (1946) Discussion. Ann. Surg. 124, 877.
Parsons, F.M., BlagG, C.R. \& Williams, R.E. (1963) Chemistry, therapy and haemodialysis of acute renal failure. Biochem. Clin. 2, 457.

PARSONS, F.M. \& FORE, H. (1963) High carbohydrate intake for oral use in acute renal failure. Lancet, ii, 386.

Parsons, F.M., Hobson, S.M., Blagg, C.R. \& McCracken, B.H. (1961) Optimum time for dialysis in acute reversible renal failure. Lancet, i, 129.

Parsons, F.M. \& McCracken, B.H. (1957) The artificial kidney. Brit. J. Urol. 29, 424.

Parsons, F.M. \& McCracken, B.H. (1959) Artificial kidney. Brit. med. J. i, 740.

Peterson, H. De C. \& Swanson, A.G. (1964) Acute encephalopathy occurring during hemodialysis. Arch. intern. Med. 113, 877.

Price, J.D.E. \& Palmer, R.A. (1960) A functional and morphological follow-up study of acute renal failure. Arch. intern. med. 105, 90.

Quinton, W., Dillard, D. \& SCRIBNer, B.H. (1962) Cannulation of blood vessels for prolonged hemodialysis. Trans. Amer. Soc. artif. intern. Org. 8, 315.

Rath, C.E., Maillard, J.A. \& Schreiner, G.E. (1957) Bleeding tendency in uremia. New Engl. J. Med. 257, 808.

Relman, A.S., Lennon, E.J. \& LemanN, J., JR (1961) Endogenous production of fixed acid and the measurement of the net balance of urea in normal subjects. J. clin. Invest. 40, 1621.

Rose, W.C., Coon, M.J. \& Lambert, G.F. (1954) The amino acid requirement of man. J. biol. Chem. 210, 331.

Salisbury, P.F. (1958) Discussion: The nature of the uremic state. Trans. Amer. Soc. artif. intern. Org. 4, 178.

SChloerb, P.R. (1958) Gastrodialysis in renal failure. Surg. Forum, 9, 14.

SCRIBNer, B.H. \& CANER, J.E.Z. (1960) Continuous hemodialysis in humans. Clin. Res. 8, 136.

SCRIBNER, B.H., CANER, J.E.Z., BurI, R. \& QUINTON, W. (1960a) The technique of continuous hemodialysis. Trans. Amer. Soc. artif. intern. Org. 6, 88.

SCRibner, B.H., Magid, G.J. \& Burnell, J.M. (1960b) Prophylactic hemodialysis in the management of acute renal failure. Clin. Res. 8, 136.

SELYe, H. (1940) The effect of testosterone on the kidney and on the general condition of uraemic animals. Canad. med. J. 42, 189.

ShupaCK, E., UricheK, P. \& Merrill, J.P. (1960) The long-term maintenance of a bilaterally nephrectomised man by periodic hemodialysis. Trans. Amer. Soc. artif. intern. Org. 6, 88.

Sirota, J.H. \& Kroop, I. (1951) Water and electrolyte disturbance in acute renal insufficiency. Fed. Proc. 10, 126.

SitPriJa, V. \& Holmes, J.H. (1962) Preliminary observations on the drop in intracranial pressure and intraocular pressure during hemodialysis. Trans. Amer. Soc. artif. intern. Org. 8, 300.

SKegGS, L.T., JR \& LeONARDS, J.R. (1948) Studies in artificial kidney. Science, 108, 212.

SwaN, R.C. \& Merrill, J.P. (1953) The clinical course of acute renal failure. Medicine (Baltimore), 32, 215.

TAYLOR, W.H. (1957) Management of acute renal failure following surgical operation and head injury. Lancet, ii, 703.

Teschan, P.E., O'Brien, T.F. \& BaXter, C.R. (1959) Prophylactic daily hemodialysis in the treatment of acute renal failure. Clin. Res. 7, 280.

ThalHimer, W. (1938) Experimental exchange transfusions for reducing azotemia: use of artificial kidney for this purpose. Proc. Soc. exp. Biol. (N.Y.), 37, 641.

WeGNER, G. (1877) Chirugische Bemerkungen über die Peritoncalholhe mit besonderer Berucksichtigung der Ovariotomie. Arch. klin. Chir. 20, 51.

Wolthuis, F.H. (1961) Balance studies on protein metabolism in normal and uraemic man. Acta med. scand. Suppl. 373. 